\title{
Enhancing Fire Resistance of Steel Bridge Girders Using External Fire Insulation
}

\author{
Esam M. Aziz \\ Department of City Planning \\ Technical College of Engineering \\ Sulaimani Polytechnic University \\ Sulaimani, Iraq \\ esam.m.aziz@gmail.com
}

\begin{abstract}
Fire in steel bridges can be a significant hazard; however, no provisions are specified for fire resistance of bridge structural members in current codes and standards. This paper presents results from numerical analysis on the response of steel bridge girders under fire conditions. A finite element model is developed to evaluate the fire resistance of typical steel girders in bridges using fire insulation with different configurations and thicknesses. The first configuration comprised of applying fire insulation on the web plate of the steel girder, while in the second configuration, the steel section is insulated. Results from numerical analysis indicate that fire resistance and failure mode in steel bridge girders is highly influenced by the insulation configuration and thickness. Applying 25.4mm fire insulation on web plate of steel bridge can increase the fire resistance up to 53 minutes, while applying same insulation thickness on steel section can result in 110 minutes fire resistance.
\end{abstract}

Keywords: Bridge fires, fire resistance, steel bridge girders, finite element analysis.

\section{INTRODUCTION}

Bridges are to be designed for many hazards such as earthquake, impact, and wind. One of the hazards that might occur in case of bridges is fire. Fire in bridges has become an increasing problem in recent decades due to increasing of transportation of combustible materials, [1, 2]. Damage or collapse of bridges arising from such fires can lead to significant economic loss and traffic delay. (see Figure 1). However, to date there are no specific fire resistance provisions in bridge design codes and standards to enhance structural fire safety of bridges [3, 4]. This is in contrast to buildings where enough fire resistance is provided to prevent collapse in the event of a fire.

The main reason of bridge fires is crashing of fuel transporting trucks and burning of gasoline underneath the bridge. These hydrocarbon fires are much more intense, as compared to building fires, and grow at a rapid heating pace and produce very high peak temperature within first five minutes. In some cases, such severe fires can pose a risk to stability of structural members and can result in partial or complete collapse of bridges. Stability of a bridge under such fire exposure depends on key factors, namely; fire intensity, material type, and characteristics of structural members [2].

The fire response of structural members in bridges can be different than those in building. This is due to differences in fire severity, applied load ratio, boundary conditions, fire insulations, and sectional dimensions of structural members. Therefore, the fire safety information that is specially established for structural members in buildings might not be applied directly for bridge structural members. There is only limited research that has been carried out on fire resistance of structural members of bridges [5-12]. Most of these studies focused on assessing fire response of steel bridge, while very few of these studies aimed to enhance the fire resistance of steel bridge girders [2, 12]. This paper discusses results from numerical studies on enhancing the fire resistance of steel bridge girders exposed to fire using application of fire insulations.

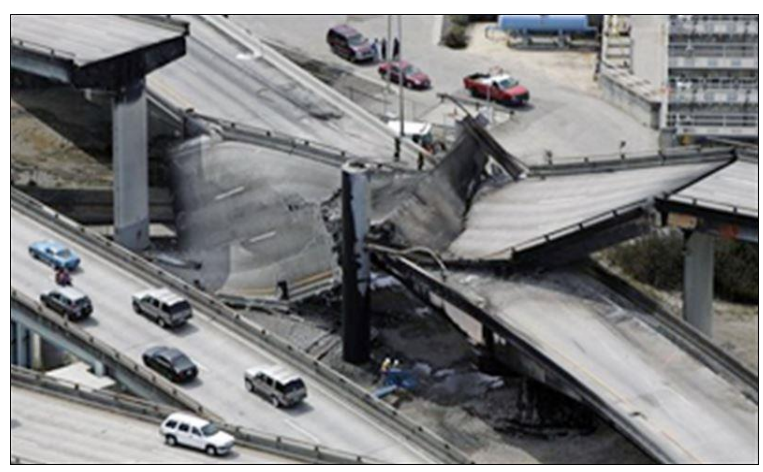

Figure 1. Oakland highway bridge collapse under fire due to gasoline tanker crashing, California, USA, 2007

\section{NUMERICAL MODELING}

A numerical model is developed using ANSYS software program for tracing the response of fire exposed steel bridge girders [13]. Uncoupled thermo-mechanical analysis was undertaken for tracing thermal and structural response of a bridge girder. Structural components of the composite girder (shown in Figure 2(a)), including steel girder, concrete slab, shear studs and stiffeners, were discretized with different elements available in ANSYS.

The thermal analysis of the steel-concrete girder is carried out using SOLID70 and SURF152 elements. To simulate the steel girder, slab, and the stiffeners, SOLID70 elements are used. SOLID70 is a 3-D element, capable for three-dimensional thermal conduction. SURF152 element is utilized for simulating surface effects such as thermal radiation and heat convection. The discretization used for thermal analysis is shown in Figure 2(b). In thermal analysis, thermal properties for 
steel and concrete at elevated temperatures; including thermal conductivity, specific heat and thermal expansion, were provided as input into ANSYS program and these properties are assumed based on relations specified in Eurocodes 1, 2, and 3 [14, 15, 16].

In structural analysis, SHELL181 elements were used to model the bottom flange, web, top flange and stiffeners of the steel girder, while the concrete slab was modeled with SOLID185 elements. These elements have the capability to account for plasticity, stress stiffening, and large strain effects. To simulate the composite action between the top flange of the steel girder and the concrete slab, 3-D nonlinear surface-to-surface fully bonded contact elements (CONTA174/ TARGE170) are used. Temperatures generated from thermal analysis were applied as a thermal loading on the structural elements to simulate conditions of fire exposure on steel girder. The high temperature mechanical properties (stress-strain relationships) of steel and concrete from Eurocode 2 and Eurocode 3 provisions are used and these relations are provided as input into ANSYS program $[15,16]$. The 3-D structural model for structural analysis is shown in Figure 2(c).

Under fire exposure, steel bridge girders experience high temperatures and thus web shear buckling might be the dominant failure mode due to higher thickness of web plate as compared to the flanges. Furthermore, significant deflections can occur under fire conditions due to high thermal gradients along the girder crosssection, and due to rapid deterioration of strength and stiffness of steel. Therefore, web shear buckling (instability) and deflection criteria were also applied in defining failure. The failure is attained when the midspan deflection of the girder exceeds $(\mathrm{L} / 30)$ or when web out-of-plane displacement leads to runaway displacement [17].

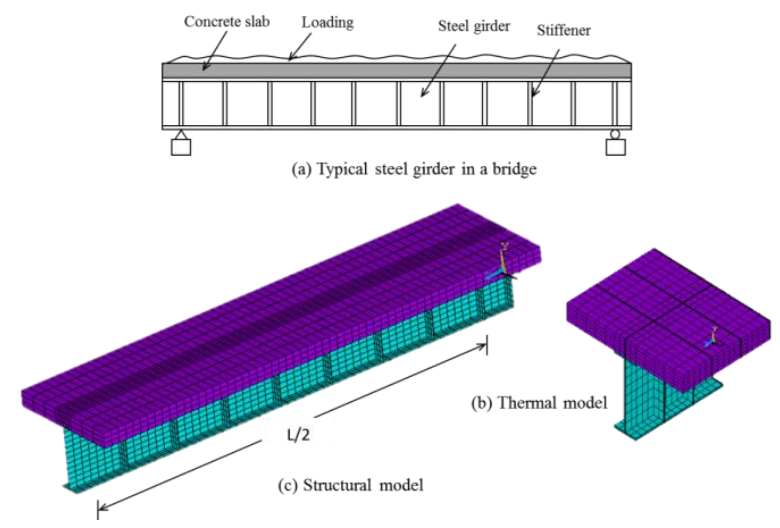

Figure 2. 3-D discretization of the typical steel girder used in numerical analysis

\section{MODEL VALIDATION}

The developed numerical model was validated against data from fire resistance tests on typical steel bridge girders (named as SG2 and SG3) carried out at Michigan State University [8]. Steel girders SG2 and SG3 are plate girders with web slenderness $(\mathrm{D} / \mathrm{tw})$ of 123 . These girders were tested under ASTM E119 fire exposure and subjected to applied loading of $40 \%$ and $33 \%$ of their flexural capacity, respectively. This is equal to $56 \%$ of their shear capacity. The developed model was validated for both thermal and structural response. Results from numerical analysis were compared with data measured during fire tests.

For thermal response validation, predicted steel and concrete temperatures are compared against corresponding temperatures measured in fire tests as shown in Figure 3(a). Predicted temperatures from the analysis match well with data measured from fire tests for entire fire exposure duration, with minor differences. This is due to variation of heat transfer parameters used in numerical analysis as compared to actual conditions present in the furnace conditions. As part of structural response validation, mid-span deflections predicted by numerical model are compared with those measured in fire tests (see Figure 3(b)). Mid-span deflections from ANSYS compare well with those measured during fire tests. Also, failure time predicted from analysis match well with failure time observed during fire test with slight variation in case of girder SG3.

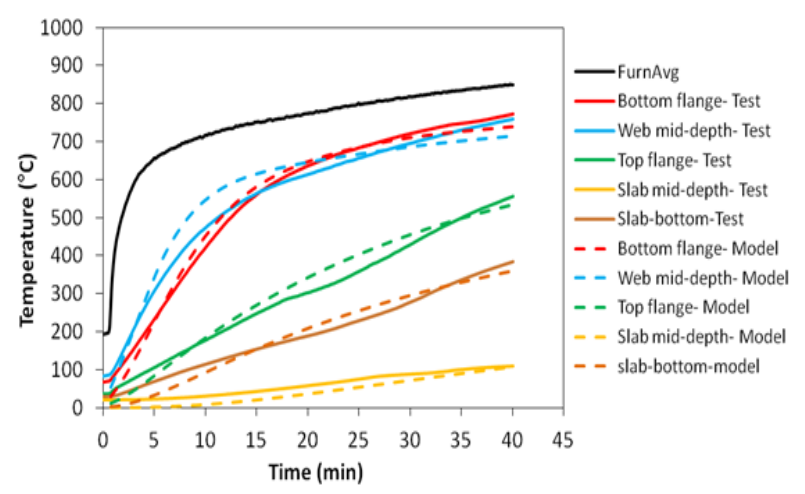

(a) Thermal response

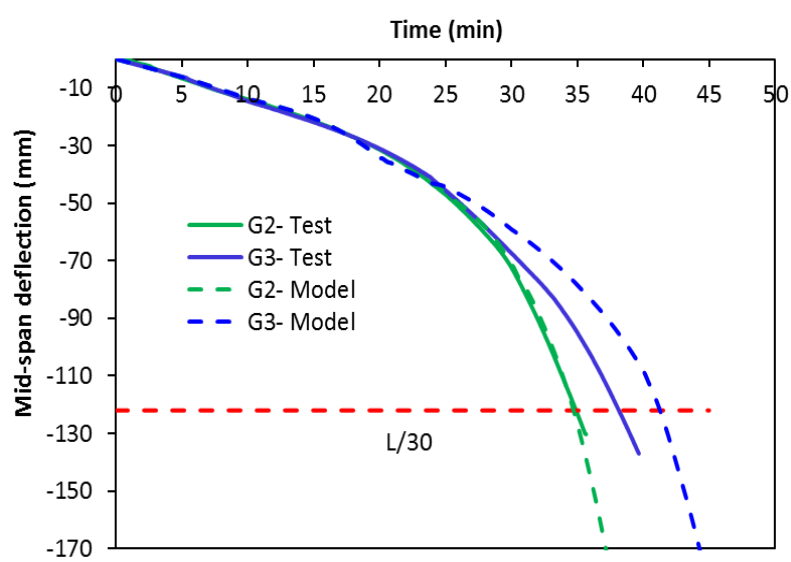

(b) Structural response

Figure 3. Comparison of predicted and measured thermal and structural response in steel girders SG2, and SG3 


\section{NUMERICAL ANALYSIS}

The validated numerical model is applied to trace the fire response of a typical steel bridge girder. In the analysis, the selected girder shown in Figure 4 is subjected to a given fire scenario and load level of $30 \%$ of room temperature flexural capacity of the girder. Results from structural analysis are evaluated in terms of mid-span deflection and web out-of-plane displacement (near the support) as a function of fire exposure time to quantify the effect of fire insulation on fire resistance of steel girders.

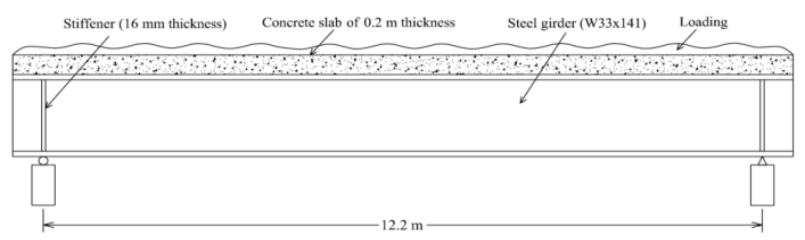

(a) Longitudinal section

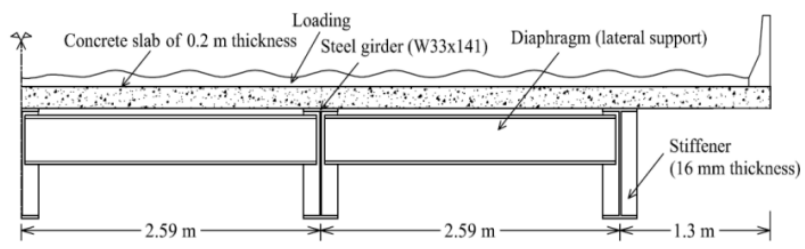

(b) Traverse section near supports

Figure 4. Typical steel bridge girder used in analysis

\subsection{Enhancing Fire Resistance in Steel Bridge Girder}

In this study, two insulation configurations are proposed to enhance fire resistance of steel bridge girders using different thicknesses. Summary of the numerical analysis results are illustrated in Table 1.

Table 1: Summary results of test parameters from numerical analysis

\begin{tabular}{|c|c|c|c|}
\hline $\begin{array}{c}\text { Insulation } \\
\text { configuration }\end{array}$ & $\begin{array}{c}\text { Insulation } \\
\text { thickness } \\
(\mathbf{m m})\end{array}$ & $\begin{array}{l}\text { Constant } \\
\text { parameters }\end{array}$ & $\begin{array}{c}\text { Fire } \\
\text { resistance } \\
\text { (minutes) }\end{array}$ \\
\hline \multirow{4}{*}{$\begin{array}{l}\text { Applying } \\
\text { insulation on } \\
\text { web plate } \\
(2 \text { sides })\end{array}$} & 6.4 & \multirow{4}{*}{$\begin{array}{c}\text { Load } \\
\text { level=30\%, } \\
\text { Hydrocarbon } \\
\text { fire, } \mathrm{D} / \mathrm{tw}=50\end{array}$} & 19 \\
\hline & 12.7 & & 31 \\
\hline & 19 & & 43 \\
\hline & 25.4 & & 53 \\
\hline \multirow{4}{*}{$\begin{array}{c}\text { Applying } \\
\text { insulation on } \\
\text { steel section } \\
\text { (3 sides) }\end{array}$} & 6.4 & \multirow{4}{*}{$\begin{array}{c}\text { Load } \\
\text { level=30\%, } \\
\text { Hydrocarbon } \\
\text { fire, D/tw }=50\end{array}$} & 28 \\
\hline & 12.7 & & 48 \\
\hline & 19 & & 80 \\
\hline & 25.4 & & 110 \\
\hline
\end{tabular}

\subsection{Apply Fire Insulation on Web Plate}

Results from previous research studies on fire response of steel bridge girders show that high web slenderness in steel bridge girder (thinner web plate as compared to flanges) makes steel girder more susceptible to web bucking due to rapid increase of temperature in the web as compared to flanges $[10,18]$. This result in failure through web shear buckling that occurs earlier than flexural failure mode. Therefore, one of the feasible ways to enhance the fire resistance of steel girder in bridges is through insulating the web plate from both sides.

To study the effect of insulating web plate on the fire response of steel bridge girder, four insulation thicknesses are applied including; $6.4 \mathrm{~mm}, 12.7 \mathrm{~mm}$, $19 \mathrm{~mm}$, and $25.4 \mathrm{~mm}$. The cross-sectional temperature profile in the girder for $25.4 \mathrm{~mm}$ insulation thickness case under hydrocarbon fire is plotted in Figure 5, while the structural response of the steel girder under these cases is plotted in Figure 6. Results show that applying $12.7 \mathrm{~mm}$ of fire insulation on web increases the fire resistance from 14 to 31 minutes. Furthermore, using thicker insulation on the web (of $25.4 \mathrm{~mm}$ ) can increase fire resistance to 53 minutes. This is due to thermal effect of insulation that results in lower temperatures in the web. As a result, the shear capacity of the girder degrades at a slower pace. Therefore, no web buckling is indicated in Figure 6(b) when insulation applied on the web. The insulated web results in lower temperature progression in the bottom flange to some extend due to redistribution of the heat in the section, but without decreasing the thermal gradients across the section significantly. For these reasons, the failure mode in the girder altered from web shear buckling to flexural bending.

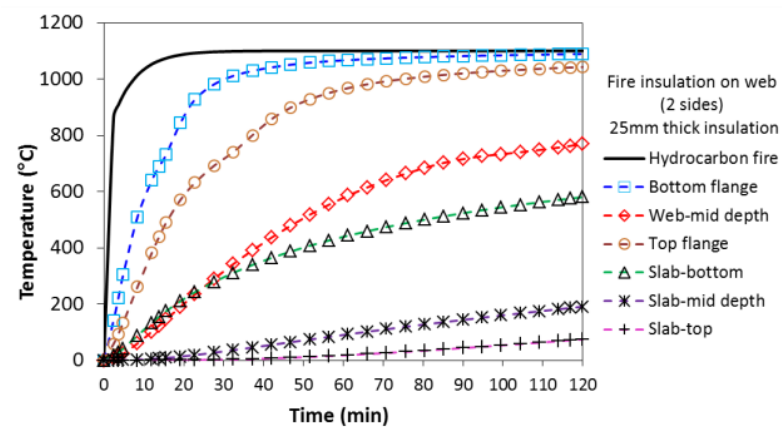

Figure 5. Progression of cross-sectional temperatures in steel bridge girder with $25.4 \mathrm{~mm}$ insulation thickness on web plate

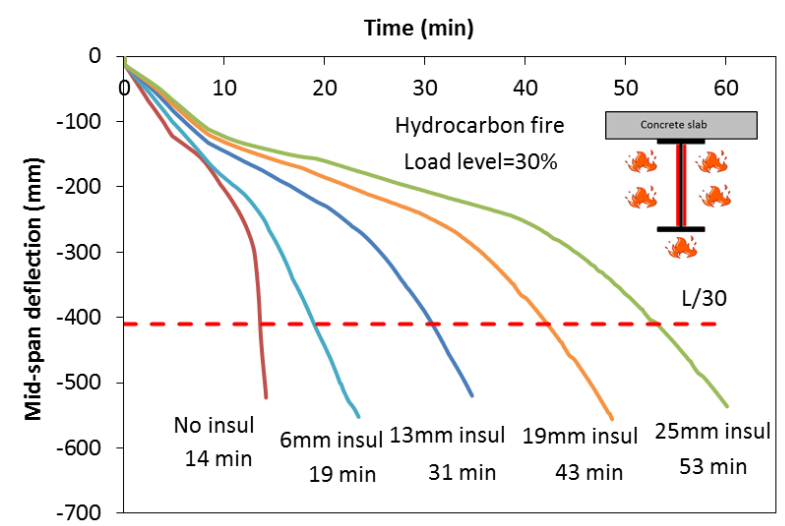

(a) Mid-span deflection 


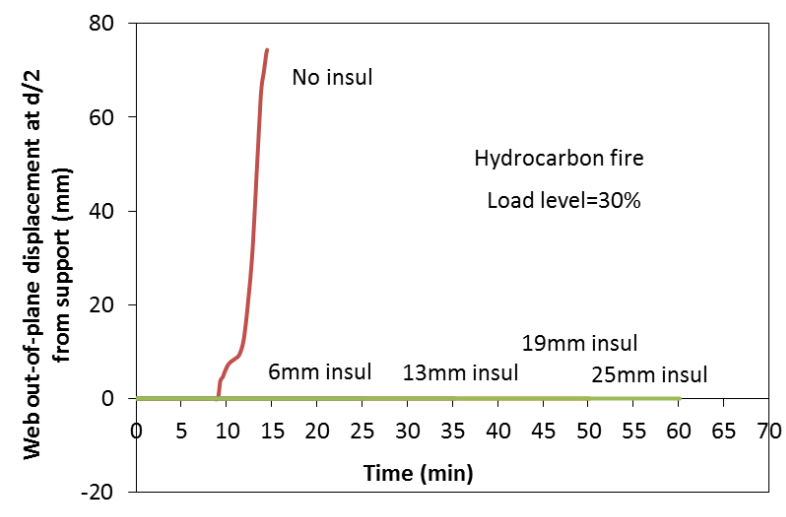

(b) Web out-of plane displacement

Figure 6. Enhancing fire resistance of a steel bridge girder through applying fire insulation on the web plate (2 sides)

\subsection{Apply Fire Insulation on Steel Girder Section}

Results from previous section (applying fire insulation on web plate) show that insulating web plate from two sides, enhances the fire resistance in steel bridge girders by protecting web plate, as a result prevent failure through web shear buckling. However, when the web is well insulated, the failure occurs through flexural yielding since the bottom flange is not insulated and can experience rapid raise in temperature. Therefore, the other way to enhance the fire resistance of steel bridge girders is to insulate the steel girder on all three sides.

To see the effect of insulation the steel section on the fire response of steel bridge girders, four insulation thicknesses are applied; $6.4 \mathrm{~mm}, 12.7 \mathrm{~mm}, 19 \mathrm{~mm}$, and $25.4 \mathrm{~mm}$. The temperature profile in the girder for $25.4 \mathrm{~mm}$ insulation thickness case under hydrocarbon fire is plotted in Figure 7, while the structural response of the steel girder under these cases is plotted in Figure 8.

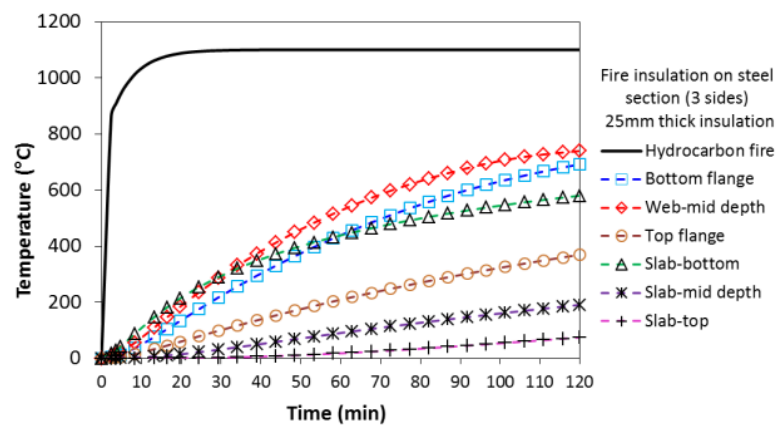

Figure 7. Progression of cross-sectional temperatures in steel bridge girder for $25.4 \mathrm{~mm}$ insulation thickness on steel section

It can be seen that using $12.7 \mathrm{~mm}$ fire insulation increases fire resistance from 14 to 48 minutes. Furthermore, increasing the insulation thickness to 25.4 $\mathrm{mm}$ can increase the fire resistance to 110 minutes. This is due to the presence of insulation that leads to slower raise in web and flanges temperatures.

Also, it can be seen the extent of mid-span deflection in Figure 8 is much lower as compared to mid-span deflection in Figure 6 for the first $10 \mathrm{~min}$ of fire exposure. This is due to low thermal gradients generated in the case of insulating the whole section of the girder as compared to high thermal gradients generated in the case of insulating only the web.

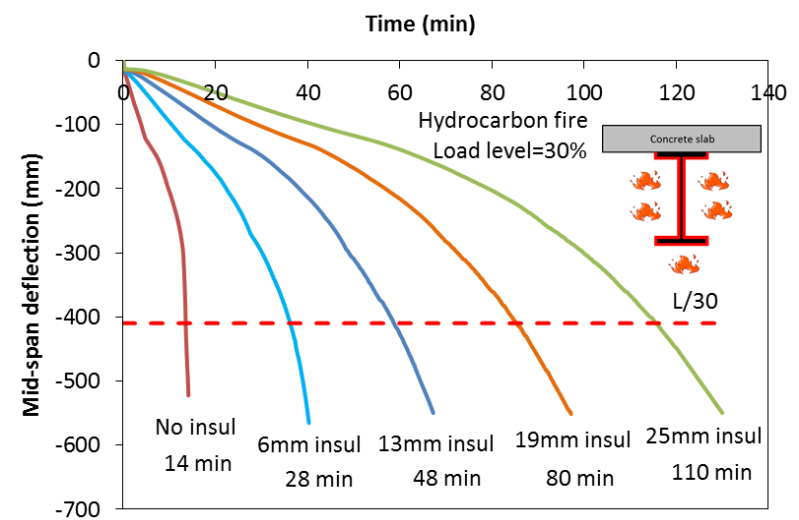

(a) Mid-span deflection

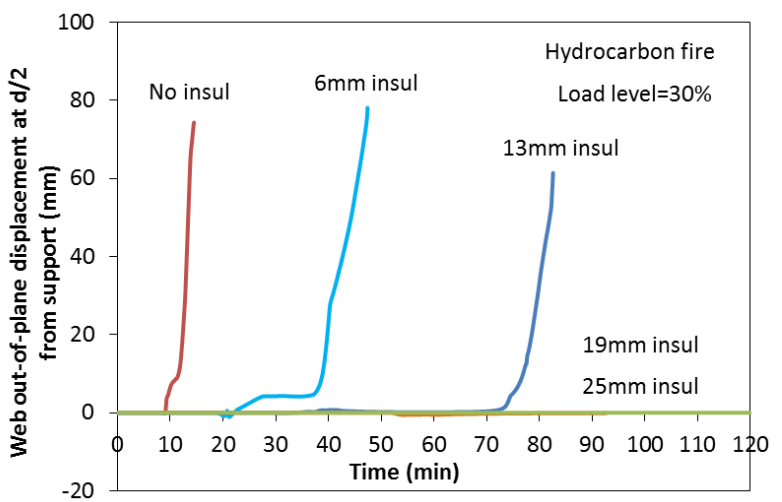

(b) Web out-of plane displacement

Figure 8. Enhancing fire resistance of a steel bridge girder through applying fire insulation on the steel section ( 3 sides)

\section{CONCLUSIONS}

Based on the results of numerical studies the following points can be concluded:

1. Steel girders in bridges can experience failure in less than 20 minutes under hydrocarbon fire exposure.

2. Under hydrocarbon fire exposure, web shear buckling is the dominant failure mode. Therefore protecting web plate can enhance the fire resistance of steel bridge girder.

3. The most effective way to enhance fire resistance of steel bridge girders is through provision of external fire insulation.

4. Applying $25.4 \mathrm{~mm}$ thick fire insulation on the web in steel bridge girder can enhance fire resistance from 14 minutes to 53 minutes.

5. Applying insulation thickness greater than $12 \mathrm{~mm}$ on the web changes the failure mode from web shear buckling to flexural yielding. Therefore, In order to enhance the fire resistance beyond an hour rating, fire insulation is to be applied on three sides of the steel girder section. 
6. Applying $25.4 \mathrm{~mm}$ thick fire insulation on the entire steel bridge girder section can enhance fire resistance up to 110 minutes.

\section{REFERENCES}

[1] V.K. Kodur, L. Gu, M.E. Garlock "Review and Assessment of Fire Hazard in Bridges". Transportation Research Board, (2172): pp. 2329, 2010.

[2] V.K. Kodur, E.M. Aziz, M.M. Dwaikat "Evaluating Fire Resistance of Steel Girders in Bridges". ASCE Journal of Bridge Engineering, vol. 18: pp. 633-643, 2013.

[3] AASHTO. AASHTO LRFD Bridge Design Specifications. Edition 4, American Association of State Highway and Transportation Officials, Washington DC, 2007.

[4] NFPA 502. Standards for Road Tunnels, Bridges, and other Limited Access Highways. Edition 2011.

[5] E.M. Aziz, V.K. Kodur "An Approach for Evaluating the Residual Strength of Fire Exposed Bridge Girders". Journal of Constructional Steel Research, vol. 88: pp. 34-42, 2013.

[6] V. Vimonsatit, K. Tan, Z. Qian "Testing of Plate Girder Web Panel Loaded in Shear at Elevated Temperature". Journal of Structural Engineering, vol. 133(6): pp. 815-824, 2007.

[7] V.K. Kodur, E.M. Aziz "Effect of Temperature on Creep in ASTM A572 High-Strength LowAlloy Steels". Journal of Materials and Structures, vol. 48(6): pp. 1669-1677, 2014.

[8] E.M. Aziz, V.K. Kodur, J. D. Glassman, M. E. Garlock "Behavior of Steel Bridge Girders under Fire Conditions". Journal of Constructional Steel Research, vol. 106: pp. 11-22, 2015.

[9] E.M. Aziz, V.K. Kodur "Effect of Temperature and Cooling Regime on Mechanical Properties of High-Strength Low-Alloy Steel”. Journal of Fire and Materials, vol. 40 (7): pp. 926-939, 2015.

[10] E.M. Aziz "Response of Fire Exposed Steel Bridge Girders". Dissertation (PhD) submitted to Department of Civil and Environmental Engineering, at Michigan State University, East Lansing, USA, 2015.

[11] J.D. Glassman, M.E. Garlock, E.M. Aziz, V.K. Kodur "Modeling Parameters for Predicting the Ultimate Postbuckling Shear Strength of Steel Plate Girders". Journal of Constructional Steel Research, vol. 121: pp. 136-143, 2016.

[12] E.M. Aziz, V.K. Kodur, M.Z. Naser "Strategies for Enhancing Fire Performance of Steel Bridges". Journal of Engineering Structures, vol. 131: pp. 446-458, 2016.

[13] ANSYS. ANSYS metaphysics. Version 14.5 ANSYS Inc. Canonsburg, PA, USA, 2013.

[14] European Committee for Standardization (CEN). EN 1991-1-2: 2002. Eurocode 1: Actions on Structures. Part 1.2 General Action-Action on
Structures Exposed to Fire. CEN, Brussels, Belgium, 2002.

[15] European Committee for Standardization (CEN). EN 1992-1-2: 2004 Eurocode 2: Design of Concrete Structures. Part 1.2 General RulesStructural Fire Design. CEN, Brussels, Belgium, 2004.

[16] European Committee for Standardization (CEN). EN 1993-1-2: 2005 Eurocode 3: "Design of Steel Structures. Part 1.2 General Rules-Structural Fire Design. CEN, Brussels, Belgium, 2005.

[17] D.E. Wainman, B.R. Kirby Compendium of UK Standard Fire Test Data for Unprotected Steel-1. Published by British Steel Technical and Swinden Laboratories, Rotherham, UK, 1989.

[18] V.K. Kodur, E.M. Aziz "Factors Governing Response of Steel Bridge Girders under Fire Conditions". Proceeding of $9^{\text {th }}$ Structural in Fire (SIF) Conference. Princeton University, Princeton, USA, 2016.

\section{Biography}

Esam M. Aziz, has Ph.D in structural fire engineering from Michigan State University in USA. His research work mainly focuses on evaluation of fire resistance of concrete and steel structural system through fire experiments and numerical modeling; characterization of materials at elevated temperatures. Also, he is involved in designing structures for fire safety, and assessing structural system in buildings/ bridges after fire exposure. https://scholar.google.com/citations?user=3i801g4AAA AJ 